\title{
ERRATUM
}

\section{TRANSMEMBRANE ADAPTOR PROTEINS: ORGANIZERS OF IMMUNORECEPTOR SIGNALLING}

Václav Hořejší, Weiguo Zhang and Burkhart Schraven

Nature Reviews Immunology 4, 603-616 (2004).

When published, in Figure 2, the tyrosine-based signalling motifs of the molecule LIME were misaligned. See the corrected version below.

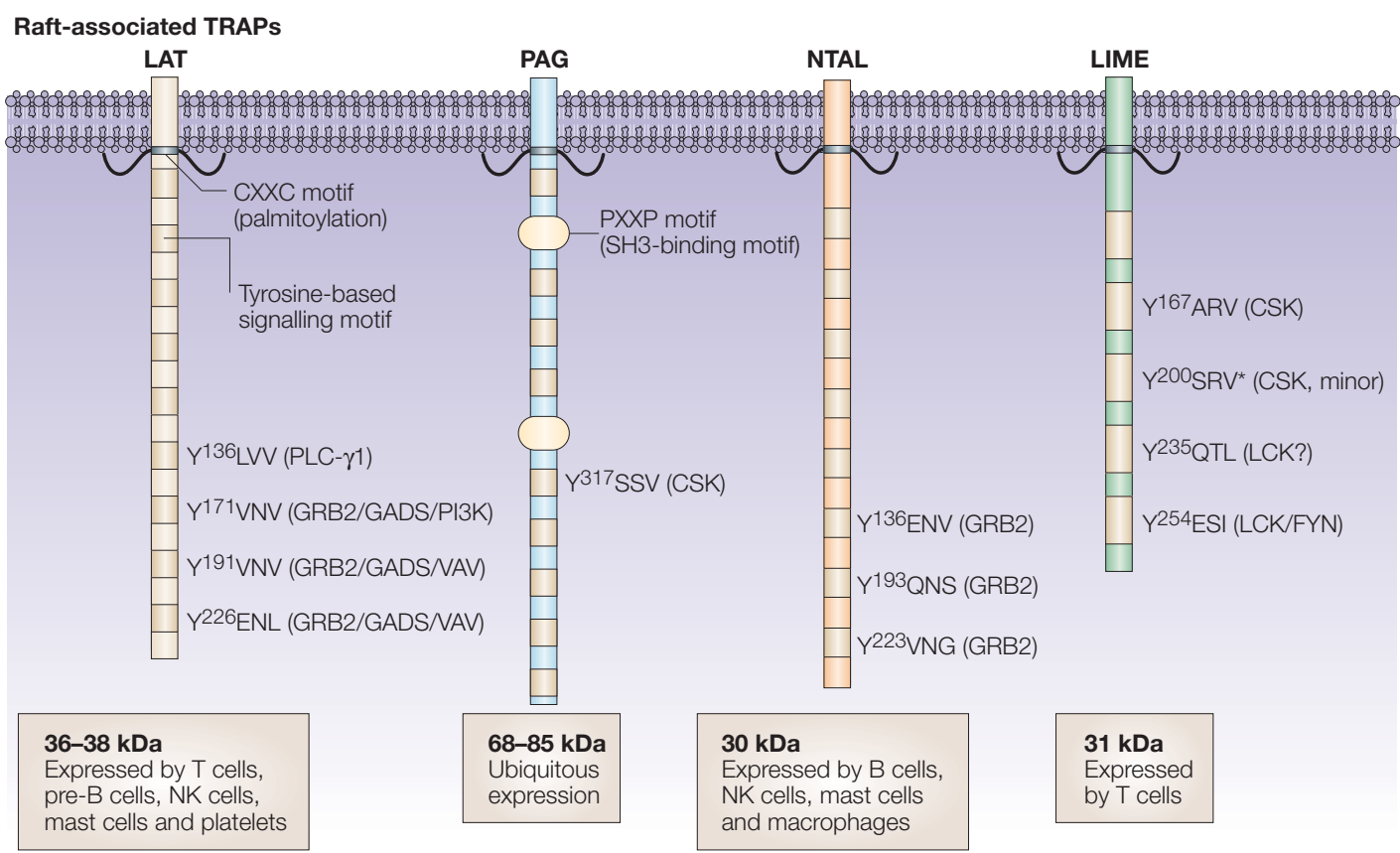

\section{Non-raft-associated TRAPs}

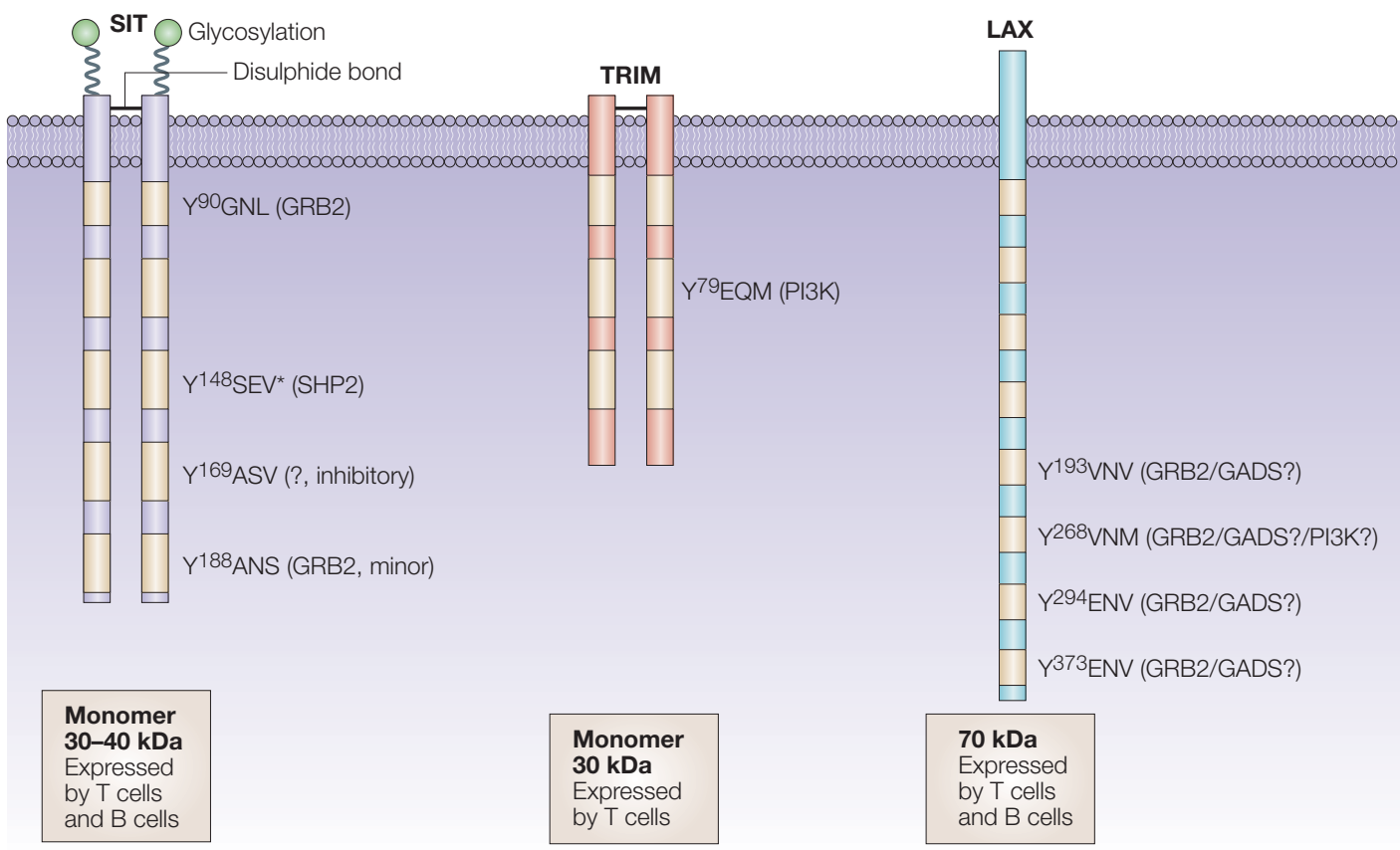

